\title{
Pengaruh Suhu dan Lama Penyimpanan terhadap Kadar Glukosa pada Nasi Putih
}

\author{
Purbowati $^{1}$, Riva Mustika Anugrah ${ }^{2}$ \\ 1,2Program Studi Gizi, Universitas Ngudi Waluyo, Ungaran,Indonesia \\ email_meika_purbo@yahoo.co.id
}

\begin{abstract}
This study aimed to understand the difference of glucose levels in electrical strored rice i.e. rice cooker and the glucose level of rice stored at room temperature at 0, 6, and 12 hours. This study used a completely randomized design (CRD) with 2 treatment groups (electrical stored rice and room temperature stored rice). Storage time is 0, 6, and 12 bours. Each treatment was conducted with 3 repetitions. The glucose levels were measured using spectrophotometry method. The Kruskal Wallis test was used to analyze the glucose level difference of 2 treatment groups. The glucose level electrical stored rice at 6, and 12 bours storage were 3,31\%, and 2,16\% consecutively. Whereas the glucose level room temperature stored rice at 6 and 12 hours storage were 2,60\% and $2,16 \%$ respectively. Bivariate analysis showed that there were significant differences of the glucose levels at 6 hours storage, however there was no significant difference at 12 hours storage. There was a massive decrease of the glucose levels during storage for both of the treatment groups.
\end{abstract}

Keywords: Rice, glucose levels, storage temperature

\begin{abstract}
Abstrak
Tujuan penelitian ini untuk mengetahui perbedaan kadar glukosa nasi yang disimpan di rice cooker dan nasi yang disimpan pada suhu ruang dengan waktu simpan selama 0, 6, dan 12 jam. Penelitian ini menggunakan desain rancangan acak lengkap (RAL) dengan 2 kelompok perlakuan (nasi yang disimpan di dalam rice cooker dan nasi yang disimpan pada suhu ruang). Variabel waktu penyimpanan adalah 0, 6, dan 12 jam. Masing-masing pengujian dilakukan dengan 3 kali pengulangan. Kadar glukosa diukur menggunakan metode spektrofotometri. Uji Kruskal Wallis digunakan untuk menganalisa perbedaan kadar glukosa nasi yang disimpan di dalam rice cooker dan nasi yang disimpan pada suhu ruang. Kadar glukosa nasi yang disimpan di rice cooker pada penyimpanan selama 6 dan 12 jam yaitu berturut-turut 3,31\%, dan 2,16 $\%$. Sedangkan kadar glukosa nasi yang disimpan pada suhu ruang selama 6 dan 12 jam adalah 2,60\% dan 2,16\%. Analisis bivariat menunjukkan adanya perbedaan kadar glukosa pada nasi yang disimpan di dalam rice cooker dan nasi yang disimpan pada suhu ruang pada penyimpanan selama 6 jam, tetapi tidak ada perbedaan kadar glukosa yang signifikan pada penyimpanan selama 12 jam. Terjadi penurunan kadar glukosa pada nasi selama penyimpanan, baik yang disimpan di dalam rice cooker maupun di suhu ruang.
\end{abstract}

Kata Kunci: Nasi, kadar glukosa, suhu penyimpanan 


\section{PENDAHULUAN}

Status kesehatan dipengaruhi oleh gaya hidup, terutama pola makan. Pola makan yang salah akan memicu terjadinya berbagai penyakit gangguan metabolisme, seperti hiperglikemia. Penderita hiperglikemia perlu mengkonsumsi makanan yang mengandung karbohidrat yang lambat dicerna atau karbohidrat dengan indeks glikemik rendah untuk mengendalikan kadar glukosa darah. Selain itu, konsumsi karbohidrat sederhana seperti glukosa perlu dibatasi karena dapat memicu hiperglikemia (Sulistyowati, 2016).

Glukosa pada bahan makanan merupakan jenis karbohidrat sederhana dari golongan monosakarida yang diperoleh dari hidrolisis pati (Adi, 2016) Selain itu, glukosa merupakan sumber energi, jika asupan berlebih akan dapat tertimbun menjadi lemak dan memicu terjadinya obesitas (Nova \& Yanti, 2017). Beberapa studi menunjukkan bahwa terdapat hubungan yang bermakna antara asupan karbohidrat sederhana dengan kadar glukosa darah pada penderita diabetes melitus (Listiana, Mulyasari, \& Paundrianagari, 2015).

Salah satu jenis makanan yang rutin dikonsumsi di Indonesia dengan kandungan karbohidrat tinggi adalah beras (Hardiansyah, Hardinsyah, \& Sukandar, 2017). Berdasarkan data Badan Pusat Statistik tahun 2018 konsumsi beras mencapai $114,6 \mathrm{~kg}$ per kapita per tahun. Angka tersebut lebih tinggi dari pada tahun 2014 yaitu tingkat konsumsi beras di Indonesia 84,6 kilogram per orang per tahun (Kementrian Pertanian Republik Indonesia, 2019). Tingginya tingkat konsumsi beras di Indonesia disebabkan masyarakat Indonesia yang meyakini belum makan jika belum mengkonsumsi nasi dari beras. Beras tersebut setelah dimasak menjadi nasi dikonsumsi dan dicerna akan diserap dalam bentuk glukosa dan dapat meningkatkan kadar glukosa darah. Penelitian Kustiani dan Laila (2018) menyatakan bahwa kelompok mencit diabetes yang diberikan tepung beras mengalami kenaikan kadar glukosa darah dibandingkan dengan kelompok yg diberikan ubi jalar.

Terdapat beberapa faktor yang mempengaruhi kandungan karbohidrat dan glukosa nasi yaitu jenis beras, cara pengolahan, dan cara penyimpanan (Hernawan \& Meynali, 2016; Sari et al., 2012). Kandungan glukosa pada beras putih sebesar 25,4\%, sedangkan kadar gula pereduksi termasuk glukosa pada beras sebelum dimasak 95,48\% dan mengalami penurunan menjadi 31,76\% setelah dimasak (Diyah et al., 2016). Hal ini disebabkan karena pada proses pemasakan terdapat sebagian karbohidrat yang hilang serta kandungan gula pereduksi yang rusak. Di sisi lain, analisis beberapa pengolahan nasi menunjukkan bahwa kadar glukosa nasi biasa yang dibakar dan dipanggang mempunyai kadar glukosa lebih tinggi dari pada nasi biasa. Hal ini dikarenakan nasi bakar dan nasi panggang mengalami proses pemanasan ulang sehingga terjadi penguapan air pada nasi yang lebih besar (Mukti, Rohmawati, \& Sulistiyani, 2018). 
Pada era modern saat ini, pemilihan metode mengolah nasi di masyarakat menggunakan cara yang praktis, yaitu dengan menggunakan rice cooker. Masyarakat Indonesia terbiasa memasak nasi satu kali untuk dikonsumsi dalam satu hari, sehingga nasi disimpan untuk waktu makan berikutnya agar terlindung dari faktor perusak baik yang bersifat fisik, kimia, maupun biologis. Penyimpanan nasi dapat dilakukan dalam pemanas maupun pada suhu ruang. Selama penyimpanan, bahan pangan akan mengalami perubahan mutu baik mutu fisik, kimiawi, dan biologis. Panas digunakan untuk menaikkan suhu pangan dan berperan dalam merangsang suatu reaksi kimia, misalnya pembunuh mikroba dan inaktivasi enzim. Oleh karena itu, pemanasan sebagai salah satu metode pengawetan bahan pangan. Namun pemberian panas dalam waktu yang lama dapat mengakibatkan menurunnya mutu bahan pangan seperti kandungan glukosa (Nuryani, 2013).

Tinggi atau rendahnya penurunan kandungan gizi suatu bahan pangan akibat pemasakan tergantung dari jenis bahan pangan dan suhu yang digunakan (Sundari et al., 2015). Penelitian Novianti et al. (2017) tentang analisis kadar glukosa nasi putih yang disimpan beberapa lama menyatakan hasil bahwa nasi putih yang disimpan selama 12 jam mengalami peningkatan kadar glukosa, kemudian kadar glukosa mengalami penurunan pada lama penyimpanan berikutnya. Hal ini dikarenakan pati yang bereaksi pada suhu tinggi meningkatkan kandungan gula pereduksi. Perlakuan penghangatan yang lama akan menyebabkan terjadinya pemecahan pati menjadi gula sederhana yakni glukosa, sehingga dapat meningkatkan kandungan gula pereduksi pada nasi. Proses memecah molekul amilum menjadi dekstrin, isoaltosa, maltosa, dan glukosa. Gula pereduksi merupakan gula yang mempunyai kemampuan untuk mereduksi, yang termasuk gula pereduksi yaitu glukosa, fruktosa, dan galaktosa (Rohman \& Soemantri, 2007). Berdasarkan latar belakang di atas perlu dilakukan penelitian untuk mengetahui apakah ada perbedaan kadar glukosa pada nasi yang disimpan pada suhu dan durasi penyimpanan yang berbeda.

\section{METODE}

\section{Desain, Waktu, dan Tempat}

Desain penelitian adalah penelitian eksperimental dengan pendekatan Rancangan Acak Lengkap (RAL). Variabel yang diukur yaitu kadar glukosa pada 2 kelompok nasi putih, yaitu nasi yang disimpan dalam rice cooker dan pada suhu ruang dengan waktu simpan 0 (baru matang), 6, dan 12 jam. Pengujian dilakukan dengan 3 kali pengulangan. Kadar glukosa kemudian dianalisis secara spektrofotometri (Situmorang, Simanjuntak, \& Silaen, 2010). Penelitian dilakukan pada bulan Juli 2019 di Laboratorium Pangan Universitas Kristen Setya Wacana untuk pengolahan nasi dan Laboratorium Kimia Universitas Kristen Setya Wacana untuk pengujian kandungan kadar glukosa. 


\section{Alat dan Bahan}

Alat yang digunakan dalam penelitian ini meliputi: timbangan makanan, dandang, panci, gelas ukur, rice cooker miyako dengan kapasitas $2 \mathrm{~kg}$ dengan tegangan $220 \mathrm{~V}$, termometer makanan, dan termometer suhu ruang. Adapun bahan uji pada penelitian ini yaitu beras putih menggunakan varietas IR 64. Jumlah nasi yang diuji kadar glukosa setiap sampel sebanyak 100 gram.

\section{Prosedur Penelitian}

Pengolahan beras menjadi nasi menggunakan rice cooker dengan cara pengolahan yaitu 1000 gram beras dicuci sebanyak 3 kali dan ditiriskan, kemudian dimasukkan ke dalam panci rice cooker dan ditambahkan 1640 air (Subarna, 2005). Rice cooker kemudian diaktifkan dengan menekan tombol "cooking" ditunggu hingga lampu berubah ke tanda "warm" dan tunggu selama 15 menit, kemudian nasi yang sudah matang diaduk rata. Nasi yang telah matang diambil sampel 3 kali 100 gram untuk diperiksa kadar glukosa, kemudian nasi diambil setengah bagian disimpan di bakul dalam keadaan tertutup dan diletakkan di suhu ruang. Sebagian nasi tetap disimpan di dalam rice cooker pada keadaan hangat "warm". Setelah 6 jam penyimpanan diambil 3 kali 100 gram nasi di rice cooker dan 3 kali 100 gram nasi di bakul, kemudian dilakukan pemeriksaan kadar glukosa. Hal yang sama juga dilakukan setelah 12 jam penyimpanan. Pemerikasaan kadar glukosa nasi dengan metode spektrofotometri.

\section{Analisis Data}

Data yang diperoleh dari hasil pemeriksaan kadar glukosa nasi disajikan dalam bentuk tabel. Pengolahan data menggunakan Microsoft Excel untuk menentukan rata-rata hasil kadar glukosa nasi. Uji kruskal wallis digunakan untuk menganalisa perbedaan kadar glukosa nasi yang disimpan di dalam rice cooker dan nasi yang disimpan pada suhu ruang

\section{HASIL DAN PEMBAHASAN}

Pada penelitian ini, penentuan kadar glukosa pada nasi dianalisis menggunakan metode spektrofotometri. Metode analisis secara spektrofotometri dengan berbagai jenis senyawa pengabsorbsi telah banyak dilakukan untuk penentuan glukosa pada berbagai sampel. Metode ini merupakan metode analisis standar untuk menentukan kadar glukosa (Situmorang et al., 2010). Sebaran dan perbedaan kadar glukosa pada nasi yang disimpan di rice cooker dan di suhu ruang dengan lama penyimpanan 0, 6, dan 12 jam disajikan pada Tabel 1 sebagai berikut. 
Tabel 1. Perbedaan kadar glukosa nasi yang disimpan di rice cooker dan yang disimpan pada suhu ruang

\begin{tabular}{lcccc}
\hline & $\begin{array}{c}\text { Suhu } \\
\text { Penyimpanan } \\
\text { Nasi }\left({ }^{\circ} \mathbf{C}\right)\end{array}$ & $\begin{array}{c}\text { Lama } \\
\text { Penyimpanan Nasi } \\
\text { (jam) }\end{array}$ & $\begin{array}{c}\text { Rata-rata } \\
\text { Kadar Glukosa (\%) }\end{array}$ & p \\
\hline rice cooker & 95,6 & 0 & 4,65 & 1,000 \\
suhu ruang & 95,6 & 0 & 4,65 & \\
rice cooker & 81,3 & 6 & 3,31 & 0,046 \\
suhu ruang & 25,0 & 6 & 2.60 & 1,000 \\
rice cooker & 75,1 & 12 & 2,16 & \\
suhu ruang & 20,8 & 12 & 2,16 & \\
\hline
\end{tabular}

Berdasarkan Tabel 1 dapat diketahui bahwa suhu nasi yang baru matang dimasak menggunakan rice cooker yaitu $95,6{ }^{\circ} \mathrm{C}$, semakin lama penyimpanan di rice cooker suhu pemanasan semakin menurun, yaitu menjadi $81,3{ }^{\circ} \mathrm{C}$ setelah 6 jam dan $75,1{ }^{\circ} \mathrm{C}$ setelah 12 jam. Begitu juga penyimpanan di suhu ruang juga mengalami penurunan suhu yaitu $25^{\circ} \mathrm{C}$ setelah 6 jam dan menjadi $20,8{ }^{\circ} \mathrm{C}$ setelah 12 jam. Kadar glukosa nasi mengalami penurunan selama penyimpanan, baik nasi yang disimpan di rice cooker maupun nasi yang disimpan di suhu ruang. Pada lama penyimpanan 6 jam terdapat perbedaan kadar glukosa pada nasi yang disimpan di rice cooker yaitu 3,31\% dan di suhu ruang sebesar 2,60\%. Adapun pada lama penyimpanan 12 jam kedua kelompok perlakuan nasi memiliki kandungan glukosa yang sama yaitu 2,16\%. Hasil analisis statistik uji kruskal-wallis menunjukkan bahwa pada lama penyimpanan 6 jam terdapat perbedaan kadar glukosa pada nasi yang disimpan di magic com dan di suhu ruang $(p<0,005)$, tetapi pada suhu penyimpanan 12 jam tidak ada perbedaan kadar glukosa $(\mathrm{p}>0,05)$ pada perlakuan penyimpanan nasi.

Semakin menurunnya kadar glukosa nasi yang disimpan di rice cooker pada penelitian ini sejalan dengan penelitian sebelumnya oleh Islamiyah et al. (2013) yang menunjukkan bahwa kadar glukosa nasi mengalami penurunan seiring lamanya waktu penyimpanan dalam pemanas. Hal ini terjadi karena selama penyimpanan nasi, terjadi proses oksidasi glukosa menjadi karbondioksida dan air. Begitu juga dengan penelitian Widhyasari et al. (2017) yang menunjukkan bahwa semakin lama proses pemanasan dalam rice cooker maka kadar karbohidrat pada nasi putih semakin menurun, dan kandungan air berkurang sehingga nasi akan menjadi lebih keras dan kering. Kadar glukosa nasi yang disimpan pada suhu ruang juga mengalami penurunan selama penyimpanan hingga 12 jam. Penelitian Juwita (2020) juga menyebutkan bahwa nasi yang dimasak dengan rice cooker teflon mengalami penurunan kadar glukosa pada penyimpanan suhu $70^{\circ} \mathrm{C}, 42^{\circ} \mathrm{C}$, dan $30^{\circ} \mathrm{C}$.

Pada lama penyimpanan 6 jam, terdapat perbedaan kadar glukosa pada nasi yang disimpan di mesin pemanas rice cooker dan nasi yang disimpan di suhu ruang biasa. Hal ini dikarenakan adanya perbedaan suhu pada kedua tempat penyimpanan tersebut. Penurunan suhu yang terjadi selama penyimpanan mempengaruhi kadar 
glukosa pada nasi. Hal ini diakibatkan perubahan suhu yang mempengaruhi stuktur pati pada nasi. Nasi atau beras merupakan jenis pati yang berupa rantai panjang glukosa. Pada pengolahan beras menjadi nasi terjadi proses pemanasan lalu pendinginan. Selama proses pemanasan granula pati mengalami gelatinisasi dan kehilangan kristalinitas. Kemudian pada pendinginan, molekul pati yang terpisah akan membentuk gel lalu ter-retrogradasi secara bertahap hingga menjadi kumpulan semi-kristalin yang bentuknya berbeda dari pati sebelumnya (Copeland et al., 2009). Pernyataan yang sama juga dijelaskan oleh Haliza et al., (2006), yaitu pemanasan pati dengan air berlebihan mengakibatkan pati mengalami gelatinisasi dan perubahan struktur. Pemanasan kembali dan pendinginan pati yang telah mengalami gelatinisasi juga mengubah struktur pati lebih lanjut yang mengarah pada terbentuknya kristal baru yang tidak larut, berupa pati ter-retrogradasi. Pati yang ter-retrogradasi adalah jenis pati resisten yang paling stabil dan sulit dicerna. Hal ini karena rantai amilosa yang lurus mudah tergradasi dan ketika rantai amilosa bergabung kembali (retrogradasi) akan membentuk sebuah polimer yang kompak dan sulit untuk dihidrolisis oleh enzim pencernaan (Hodsagi, 2011). Perubahan struktur pati yang mengalami retrogradasi menjadi pati resisten tersebut yang menyebabkan kadar glukosa menurun.

Penelitian sebelumnya menjelaskan bahwa nasi yang mengalami penurunan suhu dalam waktu lama akan mengalami proses retrogradasi sehingga nasi memiliki kadar pati resisten yang lebih tinggi dibandingkan dengan nasi yang baru matang. Kadar pati resisten pada nasi yang disimpan 24 jam yaitu 13,9 \pm 0,98; sedangkan kadar pati resisten pada nasi yang baru matang yaitu 9,1 \pm 1,02 (Ha, Han, \& Kim, 2012). Meningkatnya kadar pati resisten akibat penyimpanan dalam waktu yang lama tersebut akan menurunkan kadar glukosa dan daya cerna nasi (Yu et al., 2017).

Faktor yang mempengaruhi kadar glukosa dan tingkat kecernaan pati beras antara lain adalah kandungan amilosa, panjang pendeknya rantai amilopektin, derajat polimerisasi (DP) amilosa, dan amilopektin. Semakin tinggi kandungan amilosa, maka semakin mudah pati teretrogradasi (Syahariza et al., 2013; Zhu et al., 2011). Kandungan amilosa memiliki pengaruh signifikan terhadap retrogradasi pati. Nasi dengan kandungan amilosa tinggi mudah untuk mengalami retrogradasi, sedangkan amilosa rendah lambat mengalami retrogradasi (Luna et al., 2015). Pati yang mudah mengalami retrogradasi menjadi menjadi pati resisten menyebabkan kadar glukosa menurun. Sampel nasi pada penelitian ini berasal dari beras yang sama dan satu pengolahan yang sama, sehingga faktor jenis beras yang meliputi kadar amilosa dan amilopektin, serta faktor penambahan air pada saat pemasakan tidak berpengaruh. Hal tersebut yang memungkinkan penyebab tidak adanya perbedaan antara kadar glukosa nasi pada penyimpanan selama 12 jam baik yang disimpan di rice cooker maupun pada suhu ruang. 


\section{KESIMPULAN}

Kelompok nasi yang disimpan di rice cooker dan yang disimpan di suhu ruang sama-sama mengalami penurunan kadar glukosa seiring dengan lama waktu penyimpanan. Pada lama penyimpanan 6 jam, terdapat perbedaan kadar glukosa antar dua kelompok nasi. Adapun pada lama penyimpanan 12 jam, tidak ada perbedaan kadar glukosa antara dua kelompok nasi. Saran untuk penelitian selanjutnya, perlu dilakukan analisis kandungan karbohidrat total pada nasi dan respon terhadap glukosa darah setelah mengkonsumsi beberapa jenis nasi tersebut.

\section{UCAPAN TERIMA KASIH}

Penelitian ini dilakukan atas hibah dari Kementerian Riset, Teknologi, dan Pendidikan Tinggi Republik Indonesia pada tahun 2019.

\section{DAFTAR PUSTAKA}

Adi, A. C. (2016). Ilmu Gizi Teori \& Aplikasi (Karbohidrat). Jakarta: EGC.

Arrahman, H. (2018). Uji kandungan karbobidrat pada nasi putih dari beras Cianjur dan Garut yang dimasak dan disimpan menggunakan magic jar. Universitas Pasundan, Bandung.

Copeland, L., Blazek, J., Salman, H., \& Tang, M. C. (2009). Form and functionality of starch. Food Hydrocolloids, 23(6), 1527-1534. https://doi.org/10.1016/j.foodhyd.2008.09.016

Diyah, N. W., Ambarwati, A., Warsito, G. M., Niken, G., Heriwiyanti, E. T., Windysari, R., Purwanto, P. (2016). Evaluasi kandungan glukosa dan indeks glikemik beberapa sumber karbohidrat dalam upaya penggalian pangan berindeks glikemik rendah. Jurnal Farmasi Dan Ilmu Kefarmasian Indonesia, 3(2), 6773. https://doi.org/10.20473/jfiki.v3i22016.67-73

Ha, A. W., Han, G. J., \& Kim, W. K. (2012). Effect of retrograded rice on weight control, gut function, and lipid concentrations in rats. Nutrition Research and Practice, 6(1), 16-20. https:/ / doi.org/10.4162/nrp.2012.6.1.16

Haliza, W., Purwani, E. Y., \& Yuliani, S. (2006). Evaluasi kadar pati tahan cerna (PTC) dan nilai indeks glikemik mi sagu (evaluation of enzymatically resistant starch and glycemix index of sago noodle). Jurnal Teknologi Dan Industri Pangan, 17(2), 149-152.

Hardiansyah, A., Hardinsyah, H., \& Sukandar, D. (2017). Kesesuaian Konsumsi Pangan Anak Indonesia Dengan Pedoman Gizi Seimbang. Nutri-Sains: Jurnal Gizi, Pangan Dan Aplikasinya, 35. https://doi.org/10.21580/ns.2017.1.2.2452

Hernawan, E. dan Meynali, V. (2016). Analisis karakteristik Fisikokimia Beras Putih, Beras Merah, dan Beras Hitam (Oryza sativa L., Oryza nivara dan Oryza sativa L. indica). Jurnal Kesehatan Bakti Tunas Husada, 15(1).

Hódsági, M. (2011). Recent results of investigations of resistant starches Thesis book.

Islamiyah, U., Gonggo, S. T., \& Pursitasari, I. D. (2013). Profil kinetika perubahan 
kadar glukosa pada nasi dalam pemanas. Jurnal Akademika Kimia, 2(3), 160_ 165.

Juwita, L. (2020). Studi komparasi kadar glukosa pada nasi yang dimasak dengan metode rice cooker dan metode tradisional pada berbagai suhu. Journal of Nursing Care \& Biomolecular, 5(1), 25-32. https://doi.org/10.32700/jnc.v5i1.159

Kementrian Pertanian Republik Indonesia. (2019). Optimis produksi beras 2018 ,Kementan pastikan harga beras stabil.

Kustiani, A., Laila, W. (2018). Pengaruh Pemberian Ubi Jalar terhadap terhadap Kadar Gula Darah Mencit Putih Jantan (Mus Musculus) Diabetes Melitus. Nutri-Sains, 2(1).

Listiana, N., Mulyasari, I., \& Paundrianagari, M. D. (2015). Hubungan asupan karbohidrat sederhana dan aktivitas fisik dengan kadar glukosa darah pada penderita diabetes mellitus tipe 2 wanita usia 45-55 tahun di kelurahan Gedawang kecamatan Banyumanik kota Semarang. Jurnal Giz̨i Dan Kesehatan, 7(13), 129-137.

Luna, P., Herawati, H., Widowati, S., \& Prianto, A. B. (2015). Pengaruh kandungan amilosa terhadap karakteristik fisik dan organoleptik nasi instan. Jurnal Penelitian Pascapanen Pertanian, 12(1), 10. https://doi.org/10.21082/jpasca.v12n1.2015.1-10

Mukti, K. S. A., Rohmawati, N., \& Sulistiyani, S. (2018). Analisis kandungan karbohidrat, glukosa, dan uji daya terima pada nasi bakar, nasi panggang, dan nasi biasa. Jurnal Agroteknologi, 12(1), 90-99. https://doi.org/10.19184/jagt.v12i1.8333

Nova, M., \& Yanti, R. (2017). Faktor-Faktor Yang Berhubungan Dengan Obesitas Pada Orang Dewasa Di Kota Padang Panjang. Nutri-Sains: Jurnal Gizi, Pangan Dan Aplikasinya, 1(1), 12. https://doi.org/10.21580/ns.2017.1.1.1957

Novianti, M., Vanny M. A. Tiwow, V.M.A., Mustapa, K. (2017). Analisis Kadar Glukosa pada Nasi Putih dan Nasi Jagung dengan Menggunakan Metode Spektronik 20. Jurnal Akademika Kimia, 6(2), 107-112.

Nuryani. (2013). Potensi subtitusi beras putih dengan beras merah sebagai makanan pokok untuk perlindungan diabetes melitus. Media Gizi Masyarakat Indonesia, 3(3), 157-168.

Rohman, A., \& Soemantri. (2007). Analisis makanan. Yogyakarta: UGM Press.

Sari, D., Sirajuddin, S., \& Hendrayati. (2012). Pengaruh lama pemanasan dalam rice cooker terhadap kandungan zat besi $(\mathrm{Fe})$ dan total mikroba nasi putih. Media Gizi Masyarakat Indonesia, 2(1), 22-26.

Situmorang, M., Simanjuntak, E. P., \& Silaen, D. (2010). Pengembangan metode analisis spektrofotometry melalui reaksi enzimasi untuk penentuan glukosa di dalam buah-buahan. Jurnal Sains Indonesia, 34(2), 49-54.

Sulistyowati, E. (2016). Ilmu gizi teori \& aplikasi (asuhan gizi pada diabetes melitus). Jakarta: EGC.

Sundari, D., Almasyhuri, Lamid, A. (2015). Pengaruh Proses Pemasakan Terhadap Komposisi Zat Gizi Bahan Pangan Sumber Protein. Media Litbangkes, 25(4).

Syahariza, Z. A., Sar, S., Hasjim, J., Tizzotti, M. J., \& Gilbert, R. G. (2013). The 
importance of amylose and amylopectin fine structures for starch digestibility in cooked rice grains. Food Chemistry, 136(2), 742-749. https://doi.org/10.1016/j.foodchem.2012.08.053

Widhyasari, Luh MadeWidhyasari, L. M., Putri, N. L. N. D. D., \& Parwati, P. A. (2017). Penentuan kadar karbohidrat pada nasi putih dalam proses pemanasan rice cooker dengan variasi waktu. Bali Medika Jurnal, 4(2), 115-125., Putri, N. L. N. D. D., \& Parwati, P. A. (2017). Penentuan kadar karbohidrat pada nasi putih dalam proses pemanasan rice cooker dengan variasi waktu. Bali Medika Jurnal, 4(2), 115-125.

Zhu, L.-J., Liu, Q.-Q., Wilson, J. D., Gu, M.-H., \& Shi, Y.-C. (2011). Digestibility and physicochemical properties of rice (Oryza sativa L.) flours and starches differing in amylose content. Carbobydrate Polymers, 86(4), 1751-1759. https://doi.org/10.1016/j.carbpol.2011.07.017 
Halaman ini sengaja dikosongkan. 